JÓZEF MATUSZEWSKI

\title{
Ojciec i Syn - ostatni Piastowie na tronie królewskim*
}

\section{Der Vater und der Sohn - die letzten Piasten auf dem Königsthron}

1. Rola postanowień przodków i udziału możnych w decyzjach panujących. 2. Rola pieczęci. 3. Lokietkowe unieważnienie aktów pod starą pieczęcią. 4. Kazimierz Wielki chroni chłopów biskupich? 5. Wniosek.

1. Die Rolle der Ahnenbeschlüsse und der Anteil der Adligen bei den Entschlüssen der Herrscher. 2. Die Rolle des Siegels. 3. Ladislaus Lokieteks Aktenaufhebung unter altem Siegel. 4. Kasimirus der Große beschützt Bischofsbauern. 5. Schlussfolgerungen.

1.1. Średniowieczny władca - jak zresztą każdy - nie działał w próżni; musiał liczyć się z dwoma czynnikami. Raz, krępowały go postanowienia przodków; nie wypadało ich nie uszanować; więcej - wskazane było je zatwierdzić: ...ne nostrorum fiant irrita facta progenitorum, quam plurium noticie volumus eadem comendare [...] Nunc autem, quoniam nostrorum progenitorum donatio nostra tenetur esse confirmacio... (1245 SUb 2, nr 298). Bez takiej odnowy nie traciły one ważności, ale ich walor stawał jakby pod dużym znakiem zapytania ${ }^{1}$.

1.2. Po drugie, $w$ administracji państwem współdziałal z panującym drugi czynnik -- możni. Władca wydawał z reguły akty w obecności dostojników zgromadzonych na wiecu: 1278 r., KKK 1, nr 80. Pudyk kasuje bez odszkodowania omnia iura solne w Wieliczce i w Bochni, za zgodą baronów ${ }^{2}$ : ...de communi consilio et consensu baronum nostrorum destrui fecissemus et

\footnotetext{
* SKRÓTY: CPH - Czasopismo Prawno-Historyczne; KDMP - Kodeks dyplomatyczny Malopolski; KDWP - Kodeks dyplomatyczny Wielkopolski; KH - Kwartalnik Historyczny; KKK - Kodeks dyplomatyczny Katedry Krakowskiej; Pol. - Kodeks dyplomatyczny Polski; PSB - Polski slownik biograficzny; SUb - Schlesisches Urkundenbuch, oprac. i wyd. H. Appelt, W. Irgang, J. J. Menzel.

${ }^{1}$ R. G r ode ck i, Dzialalność gospodarcza Kazimierza Wielkiego (Polska Piastowska), Warszawa 1969 , s. 547.

${ }^{2}$ Loc cit.
} 
penitus annulari ${ }^{3}$. Podobnie zachowuje się Lokietek; w jego aktach uczestniczą: domini et terrigene nostri (1308 r., KDWP 2, nr 914); identycznie - Kazimierz: presentibus nobilibus et potentibus viris (1360 r., KDWP 3, nr 1443), presentibus strenuis militibus (1360 r., KDWP 3, nr 1444).

1.3. Nierównej byly owe dwa czynniki mocy. $Z$ reguły nowy władca składal oficjalne oświadczenie: uznajemy nadania swoich poprzedników, pragniemy ich zarządzenia zatwierdzić: confirmare pocius quam infirmare (KKK 1, nr 80). O takim samym nastawieniu świadczy również powszechna praktyka odnawiania dawnych przywilejów. Transumptów zachowała się moc, także wystawionych przez ostatnich Piastów na królewskim tronie, przez Władysława Łokietka i Kazimierza Wielkiego. Praktyka taka - wiemy - przetrwała aż do kresu szlacheckiej Rzeczypospolitej.

1.4. Lokietka charakteryzował szczególny pietyzm, z jakim odnosil się do Przemysła II, z którym zresztą kiedyś pozostawal w długoletnim konflikcie ${ }^{4}$. Mały książę powołuje się na: amicus noster felicis recordacionis Premislius secundus, rex Polonie (1296 r., KDWP 2, nr 751); podkreśla też, że jest nie tylko jego nastẹpcą: quod Premisl secundus, rex Polonie felicis recordacionis, cui in Regno Polonie et ducatu successimus (1297 r., KDWP 2, nr 767), ale i siostrzeńcem: (zatwierdzenie przywileju) magnifici principis Premislai, felicis memorie predecessoris ac sororini nostri (1298 r., KDWP 2, nr 794). Wyrażany wobec tegoż władcy respekt znajdował zresztą pełne uzasadnienie: byl on rzeczywiście indywidualnością wyjątkową ${ }^{5}$ Nie inaczej odnosił się do swoich przodków Kazimierz Wielki, czego świadectwem akt z 1346 r. (KDWP 2, nr 1250), będący transumptem trzech przywilejów: Władysława Laskonogiego z 1216 r., Boleslawa Pobożnego z 1258 r. oraz Przemysła II z $1260 \mathrm{r}$. A już z szczególnym pietyzmem traktowal tenże władca nadania swego ojca (por. niżej ust. 1.7).

1.5. Poprzednicy - co oczywiste - nie mogli zaprotestować, gdy aktualny wladca zlekceważyl ich postanowienia. Wiązały one zatem następców jedynie moralnie: nie wypadało dawnych nadań naruszać, albo przynajmniej należało udawać, że się je respektuje.

1.6. Inna całkiem sprawa $\mathrm{z}$ baronami: jak daleko $\mathrm{z}$ ich opinią musial się władca liczyć? Czy na zjeździe urzędniczym krępował się bardzo obecnością dygnitarzy, potentes? Czy zawsze? To przecież gra polityczna, zależna od układu sił, układu ustawicznie mobilnego. Dostojnicy to element żywy, przy tym skłonny do buntu, który - wiemy - w wypadkach skrajnych kończył

\footnotetext{
"Wystawca nie wahał się przy tym nazwać swego postępku, ,rabunkiem": per nostram spoliacionem communiter de omnibus patellis factam.

${ }^{4}$ O. B alzer, Królestwo polskie 1295-1370, t. 1, Lwów 1919, s. 309.

'Ibidem, s. 252-253, 272, 307, 338, 345; natomiast surowego o nim mniemania S. Z a ch or ow ski, Wiek XIII i panowanie Wladyslawa Lokietka, [w:] Dzieje Polski średniowiecznej, t. 1, Kraków 1995, s. 366-367.
} 
się nawet usunięciem panującego $\mathrm{z}$ tronu $\mathrm{u}^{6}$. Zatem indywidualność władcy odgrywała $w$ stosunkach $z$ baronami zawsze dużą rolę. Ale nie lekceważmy sobie i czynnika pierwszego. $\mathrm{Na}$ jego straży stali ciż sami możni, jeśli to leżało $\mathrm{w}$ ich interesie.

1.7. Monarcha uchodzil zawsze za dawcę lask. Interwencja jego możliwa we wszelkich sprawach, także kościelnych, a więc również dziesięcinnych: nadanie klasztorowi $\mathrm{w}$ Czerwińsku decimam post omnia nostra aratra in villis vicinis (1288 r., Pol. 1, nr 70). Wszakże skoro władca mógł wystawić komuś przywilej, był też wladny nadanie odwołać; dat, cui vult et cui vult, aufert ${ }^{7}$.

1.8. Przyjrzyjmy się bliżej postępowaniu dwu ostatnich królów-Piastów, postępowaniu słynnego wladcy, ukochanego ojca, Władysława, Ladislaus, illustris princeps, pater dilectus ${ }^{8}$ i jego najdroższego syneczka, wspaniałego władcy Kazimierza ${ }^{9}$, który jako pięciolatek nosił nie tylko zaszczytne miano dominus $^{10}$, ale także tytul: z Bożej laski książę Kujaw: magnifico principe, filiollo" $^{11}$ nostro, karissimo domino Kazimiro, Dei gracia duce ${ }^{12}$ Cuyavie (1315 r., KDWP 2, nr 979). Dalsze zaszczyty spotkały go w wieku dojrzałym: w 1331 r. na zjeździe w Chęcinach powierzono mu w celach wojskowych ${ }^{13}$ namiestnikostwo w Wielkopolsce i na Kujawach ${ }^{14}$, a także w ziemi sieradzkiej ${ }^{15}$. Tron królewski objął Kazimierz w 1333 r., a więc jako 23-letni młodzieniec.

2.1. Dla nadania trwałej mocy dokonanej czynności prawnej trzeba dwóch rzeczy: dokumentu, littere, i świadków, testes: instrumentorum munimine cum expressione testium perhennari (1257 r., KDMP 1, $\mathrm{nr} 44)$ : et ut omnia suprascripta rata et inviolabiliter perpetuo perseverent, presentes conscribi

${ }^{6}$ Por. O. B a 1 zer, Królestwo..., t. 1, s. 297.

${ }^{7}$ Przypomnijmy też rzymską regulę: quod principi placuit, legis habet vigorem!

${ }^{8}$ Łokietek cieszy się szczególnymi laskami Balzera, choć zobowiązań swoich nie respektował, O. Balzer, Królestwo, t. 2, s. 72; wielką jego zasługą było, że traktatu klęckiego nie dotrzymak, ibidem, s. 75. Natomiast król czeski, Wacław, to monarcha nie przebierający w środkach, ibidem, s. 4, po prostu polityczny spekulant, ibidem, s. 7.

${ }^{9}$ Por. jego biogram w PSB pióra Z. Kaczmarczyka oraz monografię J. W y r o zu m skiego, Kazimierz Wielki, Wrocław 1982.

${ }^{10}$ Wyrażenie dominus noster $\mathrm{w}$ owych czasach - pospolitą nazwą zwierzchnika politycznego, O. B a lze r, Królestwo..., t. 1, s. 427; t. 2, s. 14.

${ }^{11}$ Wyraz filiolus miał również znaczenia dalsze, mianowicie synowca, a także każdego księcia-Piasta: [Łokietek, zawierając przymierze z królem Danii i innymi panującymi, zapewnia] pro excellentissimo rege Ungarie, affine nostro, et pro omnibus nostris filiolis [...], principibus Cuiavie, Masovie, Oswantime, Bythonie et Raziborie, pro nostrisque nepotibus, Russie principibus. Przeciwstawieni tu zostali sobie: affines, filioli i nepotes (1315 r., KDWP 2, nr 976).

${ }^{12} \mathrm{O}$ treści terminu dux O. B a zer, Królestwo..., t. 1, s. 424-427.

${ }^{13}$ O. B a 1 ze r, Królestwo..., t. 2, s. 447.

14 Ibidem, s. 443.

15 Ibidem, s. 448. 
iussimus (1296 r., KDWP 2, nr 745): cum donaciones, vendiciones, resignaciones, obligaciones, empciones qualescunque non possunt obtinere robur perpetue firmitatis, nisi sollempni tytulo literarum et annotacione testium fuerint roborate $^{16}$ (1341 r., KDWP 2, nr 1203). Brak dyplomu, carencia privilegii (1321 r., KKK 1, nr 123), grozi jeśli nie utratą praw, to stawia je pod dużym znakiem zapytania.

2.2. Gwarantem ważności dokumentu jest pieczęć, sigillum. Była ona trwalsza od śmiertelnych świadków ${ }^{17}$. Pełniła zaś rolę podwójną. Tę samą, co zawsze: zapewniała autentyczność aktu prawnego ${ }^{18}$. Przy powszechnym w średniowieczu analfabetyzmie odgrywała ona druga jeszcze funkcję, stanowiła jej dowód, zrozumiały nawet dla niepiśmiennych ${ }^{19}$, a przy tym zastępowała własnoręczny podpis ${ }^{20}$. Toteż brak pieczęci, jak stwierdziliśmy, odbierał dokumentowi siłę dowodową ${ }^{21}$.

2.3. Pieczęć zapowiada się $\mathrm{z}$ reguły $\mathrm{w}$ koroboracji: presentem paginam conscribi fecimus et nostri sigilli munimine roborari [consignari] (1296 r., KDWP 2, nr 746); iussimus nostrique sigilli cyrographo communiri (1329 r., KDWP 2, nr 1095). Takich zapowiedzi setki; to niemal regula. Co prawda, mamy też niejeden przywilej nie zawierający w tekście wzmianki o pieczęci (1298 r., KDWP 2, nr 793; 1299 r., KDWP nr 821; 1325 r., KDWP 2, nr 1053, 1083); ale to zjawisko rzadsze.

2.4. Pieczęć przywieszano jedną; czasem dołączano ich więcej, kilka: (litteras) nostris sigillis duximus roborandas (KKK 1, nr 121), kilkanaście lub nawet kilkadziesiąt, wyjątkowo kilkaset ${ }^{22}$.

2.5. Pochodziły one od wystawcy dyplomu; jego pieczęc (pieczęcie) to niezbędne minimum. Dodatkowe sigilla przywieszały osoby, które były najczęściej współuczestnikami czynności prawnej, albo choćby jej świadkami. Czytelnik średniowiecznych dokumentów odnosi często wrażenie, że im więcej znalazło się pieczęci przy dyplomie, tym uchodził on za ważniejszy. Oczywiście istotna była pieczęc wystawcy; jej - powtarzamy - nie mogło zabraknąć nigdy.

2.6. Niejeden władca w ciągu swego życia posługiwał się kilkoma pieczęciami. Zmieniał je niewątpliwie świadomie. O niektórych panujących możemy powiedzieć, że prowadzili politykę pieczętną i to z jakimś wyrachowaniem. Do takich należał z pewnością Władysław Lokietek. Co wiemy o jego pieczęciach?

${ }^{16}$ Sfragistyka (Haisig), Warszawa 1960, s. 67, 74.

${ }^{17}$ Ibidem, s. 61, 70 .

${ }^{18}$ Ibidem, s. 65 i $\mathrm{n}$.

19 Ibidem, s. 65.

${ }^{20}$ Ibidem, s. 69, 71-75.

${ }^{21}$ Por. też, ibidem, s. 69, 71-75.

${ }^{22}$ Sfragistyka (Haisig), s. 99-102; ibidem, s. 223, Gumowski notuje powyżej 200 pieczęci przy jednym pergaminie! 
3.1. Władca ten w początkach $1318 \mathrm{r}^{23}$ - a zatem jeszcze przed koronacją - wydał rozporządzenie, publikowane zapewne we wszystkich ziemiach: cum sit de nostro mandato publice proclamatum (KDWP 2, nr 999), w którym ogłosil, że wszystkie jego przywileje, zaopatrzone starą pieczęcią (sub antiquo nostro sigillo), uznaje za nieważn $\mathrm{e}^{24}$ : nullius debeant esse auctoritatis aut valoris. W dziejach zarządu państwem to krok dość drastyczny, choć bynajmniej nie nowy ani wyjątkowy ${ }^{25}$.

Nie znamy bliżej okoliczności, wśród których Łokietek zdobyl się na podobnie mocne posunięcie. Racje fiskalne odegrały tu $\mathrm{z}$ pewnością swoją rolę ${ }^{26}$, choć cele polityczne przyświecały prawdopodobnie wystawcy w pierwszym rzędzie. Jest rzeczą oczywistą, że zarządzenie takie nie mogło znaleźć w kraju przychylnego dla władcy odzewu.

3.2. W powstałej nowej sytuacji należało zwrócić się do kancelarii panującego z prośbą o wystawienie duplikatu, zaopatrzonego już subappensione modernorum sigillorum. Tak właśnie postąpił specialis capellanus Lokietka - opat wąchocki, Piotr. Jemu to zawdzięczamy podaną wyżej wiadomość, która znalazła się w wystawionym dla niego lokietkowym dyplomie.

4.1. Kazimierz, nieodrodny syn Władysława, czul się upoważniony do unieważniania obowiązujących reguł. Przykładem jego rozporządzenie $w$ sprawie snopowej dziesięciny kościelnej: zakazujemy, by chłopi diecezji krakowskiej zwozili dziesięcinne zboże na swoich wlasnych wozach do stodól uposażonych tą daniną biskupa $\mathrm{i}$ innych duchownych: quod licet alias ex quibusdam causis prohibuerimus et prohiberi mandaverimus kmethonibus seu colonis dyocesis Cracoviensis, ne decimas prediales frugum suarum, tam episcopo quam aliis quibuscunque clericis debitas, suis curribus conducerent, sicut conducebantur temporibus retroactis (1352 r., KKK 1, nr 195).

4.2. Rozporządzenie wręcz zdumiewające. Regulą bylo bowiem, panującą od samego zarania osadnictwa ${ }^{27}$, że koloniści nie tylko świadczyli duchownym

${ }^{23}$ O. B a lze r, Królestwo polskie, t. 2, s. 194, przyp. 1.

${ }^{24}$ S. Kętrzy ński, O dwu pieczęciach Przemysla II z r. 1290, Miesięcznik Heraldyczny 1932, t. 11 , s. 29 , przyp. 42 .

${ }^{25}$ Podobnie postępowal jego poprzednik - Przemysł II, por. 1288 r., KDWP 2, nr 619, 632; 1295 r. KDWP 1, nr 571 (data za S. K rzyża now skim, Dyplomy $i$ kancelaria Przemyslawa II. Studium $z$ dyplomatyki polskiej XIII wieku, [w:] Pamietnik $A U$, Wydzial Filolog. i Hist.-Filozof. [Kraków] 1890, t. 8, reg. nr 77), ob. też S. E. R adzikow ski, Regnum Poloniae w oświetleniu sfragistyczno-heraldycznym, KH 1914, t. 28, s. 30, oraz O. B alzer, Królestwo..., t. 1, s. 324.

${ }^{26} \mathrm{O}$ opłatach za wystawianie przywilejów Sfragistyka (Haisig), s. 80, 84.

${ }^{27}$ Zresztą omawiany akt Kazimierzowski sam to wyraźnie potwierdza: ...sicut conducebantur temporibus retroactis. 
wspomniane decime prediales $\mathrm{w}$ naturze, ale że również zwozili je do ich stodół czy na inne wskazane miejsce, na swoich wlasnych wozach ${ }^{28}$.

4.3. Oczywiście duchowieństwo na takie posunięcie władcy od razu reaguje: zwracają się do króla $\mathrm{z}$ błaganiem o uchylenie zakazu dotkliwie dotknięci zarządzeniem duchowni krakowscy, biskup i jego kapituła. Interweniuje nawet arcybiskup gnieźnieński, de consilio [...] domini Iaroslai, sancte Gneznensis ecclesie archiepiscopi $i^{29}$.

4.4. Kazimierz bez wahania ustępuje i zarządzenie odwołuje dictam prohibicionem vecture decimalis penitus revocantes (1352 r., KKK 1, $\mathrm{nr} 195)$, przywracając stan poprzedni. Chłopi zatem znowu zobowiązani zostają do darmowej zwózki dziesięcinnego plonu, zboża i konopi, decimas frugum suarum cuiuslibet seminis et canapi tempore messis, quolibet anno, curribus suis ipsi coloni sine dolo et fraude ad orrea episcopi et clericorum vel alia certa loca villarum, in quibus huiusmodi decime consistunt, que procuratores, venditores seu decimatores aut decimarum emptores episcopi et quorumlibet canonicorum seu clericorum elegerint, conducere et componere, sicut olim fuit consuetum, perpetuis temporibus teneantur. Co więcej, gdy owe dziesięciny w naturze zostaną przez uprawnionych do ich poboru dziesięcinników sprzedane kupcom (a to jest regula, albowiem co mieli duchowni robić z masą dostarczonego im zboża i konopi?), także wówczas chłopski obowiązek zwózki dziesięcinnej daniny zostaje utrzymany, quas [decimas] cultores agrorum et coloni curribus suis ipsis etiam emptoribus ad certa loca vel orrea [...] conducere sint astricti. Wszakże w takim wypadku jako odszkodowanie za dodatkowy mozoł, racione huius laboris, zatrzymają chłopi dla siebie dziesięcinę konopną, in eo casu decimam canapi [...] sibimet reservantes ${ }^{30}$.

4.5. Nie wiemy, w jakich to okolicznościach i $z$ jakich przyczyn, ex quibusdam causis, doszło do wydania omawianego zarządzenia przez Kazimierza. Robi ono wrażenie królewskiej szykany. Bo zważmy na ograniczerie terytorialne zakazu: obowiązuje on tylko w diecezji krakowskiej! Dlaczegoź tam właśnie duchowieństwo miało znaleźć się w trudniejszej sytuacji niż w reszcie kraju? Po prostu posunięcie króla było podyktowane jego konfliktem z krakowskim biskupem!

4.6. Transport - wiadomo - to słaba strona średniowiecza. Nie znano przecież wówczas zastosowania nowoczesnych środków mechanicznych przewozu; do dyspozycji jako siła pociągowa stal jedynie kon ${ }^{31}$ (ewentualnie

\footnotetext{
${ }^{28}$ R. Grodecki, Dzialalność gospodarcza..., s. 585.

${ }^{29}$ W roboracji nazywa się tegoż arcybiskupa: huius negocii mediator.

${ }^{30}$ W czasach Dlugosza ulgi tej już nie znano (od jak dawna?); wówczas obowiązują równocześnie obie dziesięciny: zbożowa i konopna, por. O. Balzer, Królestwo..., t. 1, s. 427, oraz J. M a t u z zew sk i, Dziesiecina kościelna w Malopolsce w świetle „Liber beneficiorum" Iwana Dlugosza, [w:] Symbolae historico-iuridicae Lodzienses Iulio Bardach dedicatae, Łódź 1997, s. 35.

${ }^{31}$ Por. J. Matuszewski, Transport - przewóz w wiekach średnich, CPH 1998, t. 50, z. 1, s. $207-209$.
} 
wół). Nic więc dziwnego, że duchowieństwo małopolskie w rozterce. Nie rozporządzało ono wlasnymi środkami transportu, a produkt $\mathrm{z}$ pola zwieźć trzeba koniecznie. Należałoby zatem nająć do zwózki chłopa, ale wieśniak każe sobie za usługe dobrze zapłacić. Jedyny na to ratunek - to skłonić monarchę do odwolania tak niekorzystnej dla duchowieństwa małopolskiego decyzji.

4.7. Kazimierz to gracz nie lada ${ }^{32}$, zarządzenie odwolal. Przecież majestat królewski znany jest ze swej szczodrobliwości ${ }^{33}$, o czym monarcha zapewnia przy każdej okazji; tylko z niegodziwego poduszczenia dopuścil się niewłaściwego posunięcia, thumaczy się monarcha: ...licet ad sugestionem quorundam minus iustam... ${ }^{34}$ (1348 r., KDWP 2, nr 1275). W rezultacie, chłopi diecezji krakowskiej muszą znowu odstawiać do stodół dziesięcinnika decymę $\mathrm{w}$ każdej postaci, nie otrzymując $\mathrm{w}$ zamian wynagrodzenia, sed si decimas frugum coloni pro episcopo vel quolibet clerico conduxerint, eciam decimas lini et canapi cum semine, in manipulis solvere et conducere ad orrea teneantur.

4.8. Oczywiście ustępstwo Kazimierza nie za darmo. Ktoś musiał koszty królewskiej szczodrobliwości zapłacić. Na ten temat źródła się nie rozpisują, wprost tego nam nie mówią. Historyk domyśla się argumentu jedynego, który mógł skłonić władcę takiego jak Kazimierz do odwołania zakazu: przyznanie mu subsidium charitativum. Rzeczywiście Kazimierz decyzje zmienił bez wahania: chłopi krakowskiej diecezji ponownie zobowiązani zostają do zwózki dziesięcinnych snopów zbożowych i kit konopnych. A odległości do pokonania są nieraz bardzo duże, bo wynoszą kilkanaście, a może nawet sięgają kilkadziesiąt kilometrów ${ }^{35}$.

5. W omówionych przykładach obaj ostatni Piastowie rysują się nam jako władcy bezwzględni, pilnujący dochodów fiskusa przede wszystkim. Nie tylko

32 Przypomnijmy tu inną sytuację, o której informuje akt z 1364 r., KKK 1, nr 235: rozeszła się pogłoska, że król zamierza zmienic droge do Muszyny. Kazimierz zarzeka się, jakoby kiedykolwiek nosił się $\mathrm{z}$ podobnym zamiarem, volumus nos non latere, quod hoc ipsum nunquam cogitavimus, i obiecuje tej drogi nie zmieniać nigdy: vestram viam seu iter usquaquam alienare. Przy tej okazji jednak wystawca dodaje: ceterum vobis precipimus, ut reparacionem pontis intendatis vestro pro posse. Podejrzewamy, że to sam Kazimierz mógł rozpuścić wspomnianą pogloskę, chcąc wymóc na Muszynie rzetelną naprawę mostu.

${ }^{33} 1364$ r., KKK 1, nr 232: król zatwierdza zamianę wsi: de solita nostre regie Maiestatis benignitate graciose admittentes... Zresztą nie on jeden swą łaskawością się chelpi; to właściwość wszystkich władców, na taką ich postawę przykładów bezlik, zacytujmy następujące: $1256 \mathrm{r}$., KDMP 1, nr 43: ex innata nobis liberalitate; 1255 r., KDMP 1, nr 42 (fals.): et que per pias largiciones fiunt predecessorum, dignum est, ut per successores confirmata, rata et firma temporibus perpetuis perseverent; $1290 \mathrm{r}$., SUb 5, nr 448, 489: de innata nobis clemencia.

${ }^{34}$ Takie uzasadnienie w przywileju dla klasztoru w Leknie, por. R. Grodecki, Dzialalność gospodarcza..., s. 513.

${ }^{35}$ Por. J. M a tuszewski, Transport - przewóz..., s. 207-209. 
Lokietek, ale i rzekomy „król chłopków” nie waha się poświęcić ich interesów, by zapewnić sobie przychylność wplywowego duchowienstwa, a równocześnie nie uronić nic z dochodów skarbowych. Ostatecznie za jego szczodrobliwość zapłacą... rustici $!^{36}$

${ }^{36}$ Por. J. Matuszew ski, Dziesięcina kościelna.., s. 41. 